\title{
Going Viral
}





\section{Going Viral}

\section{Zombies, Viruses, and the End of the World}

DAHLIA SCHWEITZER

$$
\text { I: }
$$

\section{Rutgers University Press}

New Brunswick, Newark, and Camden, New Jersey, and London 
Library of Congress Cataloging-in-Publication Data

Names: Schweitzer, Dahlia, author.

Title: Going viral : zombies, viruses, and the end of the world / Dahlia Schweitzer.

Description: New Brunswick : Rutgers University Press, 2018. | Includes bibliographical references and index.

Identifiers: LCCN 2017014954 (print) | LCCN 2017057488 (ebook) | ISBN 9780813593166 (E-pub) | ISBN 9780813593180 (Web PDF) | ISBN 9780813593159 (hardback) |

ISBN 9780813593142 (paperback) | ISBN 9780813593166 (ebook)

Subjects: LCSH: Epidemics in mass media. | Apocalypse in mass media. | Mass media-

Social aspects-United States. | BISAC: PERFORMING ARTS / Film \& Video /

History \& Criticism. | SOCIAL SCIENCE / Disease \& Health Issues. | SOCIAL

SCIENCE / Media Studies.

Classification: LCC P96.E632 (ebook) | LCC P96.E632 U673 2018 (print) |

DDC $791.43 / 615-\mathrm{dc} 23$

LC record available at https://lccn.loc.gov/2017014954

A British Cataloging-in-Publication record for this book is available from the British Library.

Copyright $\left({ }^{\circ} 2018\right.$ by Dahlia Schweitzer

All rights reserved

No part of this book may be reproduced or utilized in any form or by any means, electronic or mechanical, or by any information storage and retrieval system, without written permission from the publisher. Please contact Rutgers University Press, ro6 Somerset Street, New Brunswick, NJ $\circ 890$. The only exception to this prohibition is "fair use" as defined by U.S. copyright law.

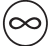

The paper used in this publication meets the requirements of the American National Standard for Information Sciences-Permanence of Paper for Printed Library Materials, ANSI Z 39.48-1992.

www.rutgersuniversitypress.org

Manufactured in the United States of America 